\title{
2021 Handbook of Florida Water Regulation: Florida Watershed Restoration Act ${ }^{1}$
}

\author{
Michael T. Olexa, Tatiana Borisova, and Jana Caracciolo
}

\section{Preface}

This handbook is designed to provide an accurate, current, and authoritative summary of the principal federal and state (Florida) laws that directly or indirectly relate to agriculture. This handbook provides a basic overview of the many rights and responsibilities that farmers and farmland owners have under both federal and state laws as well as the appropriate contact information to obtain more detailed information. However, the reader should be aware that because the laws, administrative rulings, and court decisions on which this handbook is based are subject to constant revision, portions of this publication could become outdated at any time. Several details of cited laws are also left out due to space limitations. This handbook is provided as an educational text for those interested in water use and water resource issues in Florida.

This handbook is distributed with the understanding that the authors are not engaged in rendering legal or other professional advice, and the information contained herein should not be regarded as a substitute for professional advice. This handbook is not all inclusive in providing information to achieve compliance with the federal and state laws and regulations governing water protection. For these reasons, the use of these materials by any person constitutes an agreement to hold harmless the authors, the UF/IFAS Center for Agricultural and Natural Resource Law, and UF/IFAS Extension for any liability claims, damages, or expenses that may be incurred by any person as a result of reference to or reliance on the information contained in this handbook. Note: UF/IFAS is the acronym for University of Florida, Institute of Food and Agricultural Sciences.

\section{FWRA Overview}

The Florida Legislature enacted the Florida Watershed Restoration Act (FWRA) in 1999 to protect Florida's water resources from excessive pollution loading. It focuses on the Total Maximum Daily Load (TMDL) program that is required by the federal Clean Water Act, and discusses specifics of how this program should be implemented in Florida. The TMDL program protects state waters by coordinating the control of pollution from point sources (i.e., sources discharging through a discrete conveyance, such as a pipe, as well as urban stormwater conveyance outfalls) and nonpoint sources (i.e., sources contributing to pollution caused by rainfall moving over and through the ground, such as excess fertilizer from residential and agricultural areas or bacteria from leaking septic systems).

A TMDL is the total amount of pollution discharge from all sources that a water body can assimilate and still meet water quality standards (For more information on water quality standards, see: Surface Water Quality Standards, Chapter 62-302). Water bodies that do not meet water

1. This document is FE608, one of a series of the Food and Resource Economics Department, UF/IFAS Extension. Original publication date December 2005. Revised June 2017and April 2021. Visit the EDIS website at https://edis.ifas.ufl.edu for the currently supported version of this publication.

2. Michael T. Olexa, professor, Food and Resource Economics Department, and director, UF/IFAS Center for Agricultural and Natural Resource Law; Tatiana Borisova, associate professor, Food and Resource Economics Department; and Jana Caracciolo, student, Levin College of Law; UF/IFAS Extension, Gainesville, FL 32611.

The Institute of Food and Agricultural Sciences (IFAS) is an Equal Opportunity Institution authorized to provide research, educational information and other services

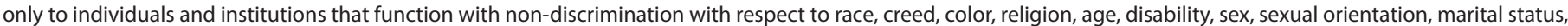

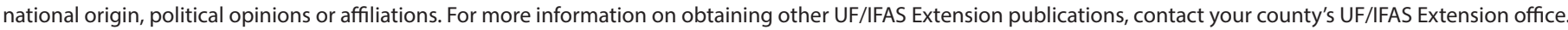
U.S. Department of Agriculture, UF/IFAS Extension Service, University of Florida, IFAS, Florida A \& M University Cooperative Extension Program, and Boards of County Commissioners Cooperating. Nick T. Place, dean for UF/IFAS Extension. 
quality standards are identified as "impaired", and for such water bodies, plans must be developed describing how the point and nonpoint sources of pollution are planning to meet their discharge allocations. Usually, this implementation plan is referred to as Basin Management Action Plan (BMAP).

The Florida Department of Environmental Protection (FDEP) identified the following basic steps for the TMDL program (the bulleted list below is a direct quotation from the FDEP website at http://www.dep.state.fl.us/water/ tmdl/):

- Assess the quality of surface waters-are they meeting water quality standards?

- Determine which waters are impaired-that is, which ones are not meeting water quality standards for a particular pollutant.

- Establish and adopt, by rule, a TMDL for each impaired water for the pollutants of concern - the ones causing the water quality problems.

- Develop, with extensive local stakeholder input, Basin Management Action Plans (BMAPs).

- Implement the strategies and actions of BMAPs.

- Measure the effectiveness of BMAPs, both continuously at the local level and through a formal re-evaluation every five years.

- Adapt BMAPs to local conditions by changing the plan and changing the actions if things are not working.

- Reassess the quality of surface waters continuously.

For the list of TMDLs and BMAPs adopted in Florida, as well as for the schedule of public meetings related to TMDL and BMAP development, see the state TMDL program website (http://www.dep.state.fl.us/water/tmdl/).

\section{Who enforces FWRA?}

Under FWRA, while FDEP is the lead agency in establishing TMDLs, the primary enforcement power is actually split between the Florida Department of Environmental Protection (FEDP) and the Florida Department of Agriculture and Consumer Services (FDACS). FDEP is the lead agency for enforcing FWRA when addressing point source and nonagricultural nonpoint source pollution. FDACS is the lead agency for enforcing FWRA when addressing agricultural nonpoint source pollution.
FWRA is unique in the establishment of TMDLs because it allows FDEP to address TMDLs through a watershed management approach in which water resources are managed based on natural boundaries rather than political or regulatory boundaries.

\section{What are the duties of FDEP under FWRA?}

FDEP is required to coordinate with the Florida water management districts (FWMDs), FDACS, Soil and Water Conservation Districts (SWCDs), environmental groups, regulated parties, and local stakeholders during all phases of the TMDL process, which includes

- Development of a TMDL assessment. The assessment methodology for determining those waters that are impaired should be adopted by FDEP by rule. The methodology should include determination of what information is required for the TMDL assessment, the acceptable methods of data collection, and analysis and quality control requirement. Recall that impaired waters are those that fail to meet the water quality standards assigned to them based on the waters' designated uses. If water bodies are determined to be impaired, FDEP must establish a TMDL.

- Development of an approved list of those water bodies or segments for which TMDL loads will be conducted, including a priority ranking and schedule for analyzing such waters.

- Calculation and implementation of TMDLs. A TMDL should account for seasonal variations and include a margin of safety to reflect uncertainties about pollution loading effects on water quality. A TMDL should be allocated among pollution sources in a reasonable and equitable manner (accounting for the availability of treatment technologies and the existing treatment levels, and the costs and benefits of achieving allocation).

FDEP in coordination with FWMDs may develop a BMAP to achieve the TMDL. BMAPs can include such strategies as construction of regional treatment systems or voluntary trading of water quality credits. BMAPs should include water quality improvement milestones, and the progress with achieving these milestones should be evaluated every five years.

FWRA encourages broad involvement of interested parties in TMDL and BMAP development aimed at achieving consensus and cooperation with proposed strategies. 
FDEP can implement TMDLs under existing water quality protection programs, such as

- Permitting and other existing regulatory programs, such as water-quality-based effluent limitations

- Non-regulatory and incentive-based programs, such as cost-share, best management practices, and public education

- Trading of water quality credits or other agreements

- Public works, including capital facilities

- Land acquisition

\section{What are the requirement under FWRA?}

Most point sources discharging pollutants into Florida waters need to have National Pollutant Discharge Elimination System (NPDES) permits. These permits are based on the available technologies for storage, treatment, recycling, and reclamation of sewage and industrial waste, and on the effluent limitations necessary to protect receiving water quality. For nonpoint sources, the requirements differ for non-agricultural and agricultural sources.

For non-agricultural nonpoint sources, FDEP must consult with the appropriate FWMD and interested parties to develop suitable best management practices (BMPs) or other measures to achieve the level of pollution reduction established by FDEP. These practices and measures may be adopted by rule by FDEP and FWMDs. When adopted in this manner, the parties responsible for the nonagricultural nonpoint source pollution must implement these practices and measures.

For agricultural nonpoint sources, FDACS may develop and adopt by rule suitable temporary measures, BMPs, or other measures to achieve the level of pollution reduction established by FDEP. FDACS must consult with FDEP, the Florida Department of Health (FDOH), FWMDs, affected farmers, and environmental groups in this development process. The effectiveness of suitable temporary measures, BMPs, or other measures to achieve the level of pollution reduction must be verified by FDEP. These practices and measures may be implemented by those parties responsible for agricultural pollutant sources in coordination with FDEP, FDACS, and FWMDs. BMP implementation is mandatory for agricultural operations in areas with an established TMDL. In such areas, farmers are required to file a Notice of Intent (NOI) about BMP implementation to FDACS, or conduct water quality monitoring to prove that they are not violating water quality standards (see AE388, Total Maximum Daily Loads and Agricultural BMPs in Florida).

For the list of BMP manuals adopted by FDACS for different agricultural operations and geographical regions, see the FDACS Office of Agricultural Water Policy website (https://www.fdacs.gov/Agriculture-Industry/Water/ Agricultural-Best-Management-Practices).

There are advantages to the implementation of agricultural BMPs, temporary measures, or other measures to achieve the level of pollution reduction. Verifying the effectiveness of these measures will provide a presumption of compliance with state water quality standards and a release from liability such that FDEP cannot institute proceedings against the owner of the source of pollution to recover costs or damages associated with the contamination of ground or surface water caused by the pollutant.

Note that measures taken by nonpoint sources (e.g., BMPs) and point sources (e.g., improved treatment technologies) may be supplemented by water quality credit trades. Specifically, a point or nonpoint source that achieves a greater pollutant reduction than required can trade those water quality credits to other sources in the area.

\section{Sources}

Chapter 403, Florida Statutes, Section 403.067

EPA, https://www.epa.gov/npdes/

npdes-permit-writers-manual

\section{Acknowledgments}

The authors are indebted to the personnel of both state and federal agencies who provided their time and advice in the preparation of this handbook. We acknowledge Carol Fountain and Susan Gildersleeve at the University of Florida for their assistance in editing this handbook. We also acknowledge funding received for updating this publication from the James S. and Dorothy F. Wershow Agricultural Law Endowment. 